\title{
Urban Rail Transit in China: Progress Report and Analysis (2008-2015)
}

\author{
Kai $\mathrm{LU}^{1,3} \cdot$ Baoming HAN ${ }^{1} \cdot$ Fang $\mathrm{LU}^{1} \cdot$ Zijia WANG $^{2}$
}

Received: 18 August 2016/Revised: 7 December 2016/Accepted: 20 December 2016/Published online: 30 December 2016

(C) The Author(s) 2016. This article is published with open access at Springerlink.com

\begin{abstract}
The rapid and large-scale construction of urban rail transit in China in recent years has drawn worldwide attention. The progress report and analysis would be a good reference for regional urban transit planning and policy, and for financial investment and service improvement in future. This paper offers a high-level summary of infrastructure statistics. In particular, this paper reviewed the spatial service coverage, passenger service performance and operational efficiency of urban rail transit in Mainland China and analyzed the development characteristics, such as the developing scales and multi-type urban rail transit modes based on the Annual Report of the China Urban Mass Transit work from 2008 to 2015. Suggestions and trends for further development of urban rail transit in China are proposed.
\end{abstract}

Fang LU

flu@bjtu.edu.cn

Kai LU

klubjtu@gmail.com

Baoming HAN

bmhan@bjtu.edu.cn

Zijia WANG

zjwang@bjtu.edu.cn

1 School of Traffic and Transportation, Beijing Jiaotong University, Beijing 100044, People's Republic of China

2 School of Civil Engineering, Beijing Jiaotong University, Beijing 100044, People's Republic of China

3 Department of Civil, Environmental, and Geo- Engineering, University of Minnesota, Minneapolis, MN 55455, USA

Editor: Xuesong Zhou
Keywords Urban rail transit - Operation statistics . Infrastructure $\cdot$ Multi-type urban rail transit $\cdot$ System development $\cdot$ Spatial service $\cdot$ Passenger service performance $\cdot$ Operational efficiency

\section{Introduction}

The urban rail transit system, including metro, tram, light rail and monorail except for inter-city high-speed rail, is the backbone of the public transit. This was especially true when Beijing held the 29th Olympic Games in 2008. From then on, many cities in China began developing and improving urban rail transit systems to mitigate traffic congestion. Urban rail transit systems have experienced a booming decade in China and received considerable public attention. Especially in the recent 5 years (from 2011 to 2015), there were 12 cities beginning to operate the urban rail transit systems, which accounts for nearly half of the operational systems.

The system infrastructure and mobility performance statistics are the bases for reviewing the operating condition and performance, which is important for the departments of transportation, transit agencies, local planning organizations and other user groups. In the USA, some institutions and companies cooperate to offer a wide variety of system performance reports [1-4]. For instance, along with highway performance data from the Federal Highway Administration and speed data collected by companies, the 2015 Urban Mobility Scorecard has been reported [2]. Moreover, some non-profit organizations collect data from news and the Internet, but the data are not official and the updated time not fixed [5]. Only several reports are published officially. It is possible to obtain the annual report on the state of transportation in Canada, 
published by the Minister of Transport since 2007 [6] and the annual statistical bulletin of the railway in China, published by the State Railway Administration, China [7].

On the other hand, unlike the high-speed railway which is managed directly by the State Railway Administration and China Railway Corporation (formerly known as Ministry of Railways of the People's Republic of China), the urban rail transit system is managed by local governments and companies. For this reason, it is relatively difficult to collect the precise and detailed operating information about urban rail transit systems in different cities because of the diversity of system types and the decentralization of their supervision.

This study collected and reviewed the urban rail statistics contained in the Annual Report of China Urban Mass Transit. Furthermore, this study summarized the corresponding socioeconomic data of the cities with urban rail transit systems in service in China, reviewed the spatial service coverage, passenger service performance, and operational efficiency during 2015. Finally, this study discussed the characteristics and trends in the next 5 years.

\section{Progress Review}

The statistics of urban rail transit (service length and construction length) from 2008 to 2015 in China are shown in Fig. 1, as well as the number of operational systems and the cities with urban rail transit projects under construction. The service length increased steadily versus time, and the average rate of increase is $373.5 \mathrm{~km}$ per year for the past 5 years. The fastest growth in terms of service length and the number of lines under construction by year was in the year of 2013 when the increase in service length exceeded $466.7 \mathrm{~km}$.

By the end of 2015, the total service length of the urban rail transit in Mainland China has reached $3293 \mathrm{~km}, 110$ lines and 2336 stations including 384 transfer stations and 125 depots owned by 25 cities. $63.6 \%$ of the lines are underground, and the rest are ground lines and elevated lines. The operational distance increased from 2896.4 to $3293 \mathrm{~km}$, an increase of $13.69 \%$ compared with the same period last year and four times longer than the service length in 2008. In 2015, 368 billion RMB (approximately equivalent to 56.6 billion US dollars) has been invested into urban rail transit construction [16], an increase of $27 \%$ compared with the same period last year. Fifty-five cities are planning to construct urban rail transit systems, and the total planning length reached $15,000 \mathrm{~km}$. The growth of service length fits an exponential function curve, as shown in Fig. 1, and the total service length in China by the end of 2016 will reach $3800 \mathrm{~km}$.

In 2008 , there were only 10 operational systems and this number doubled by the end of 2015. More and more cities choose urban rail transit systems. Figure 2 shows the operation distance from 2011 to 2015 for each operation system.

Beijing, Shanghai, Guangzhou, Shenzhen and Nanjing are the top cities among the 25 operational systems for the longest operation time and longest service distance. The service distance of these five cities accounts for over $50 \%$ of the total service length in China. With the development of other small cities, Qingdao, Nanchang and Huai'an are the new operational systems in 2015 .

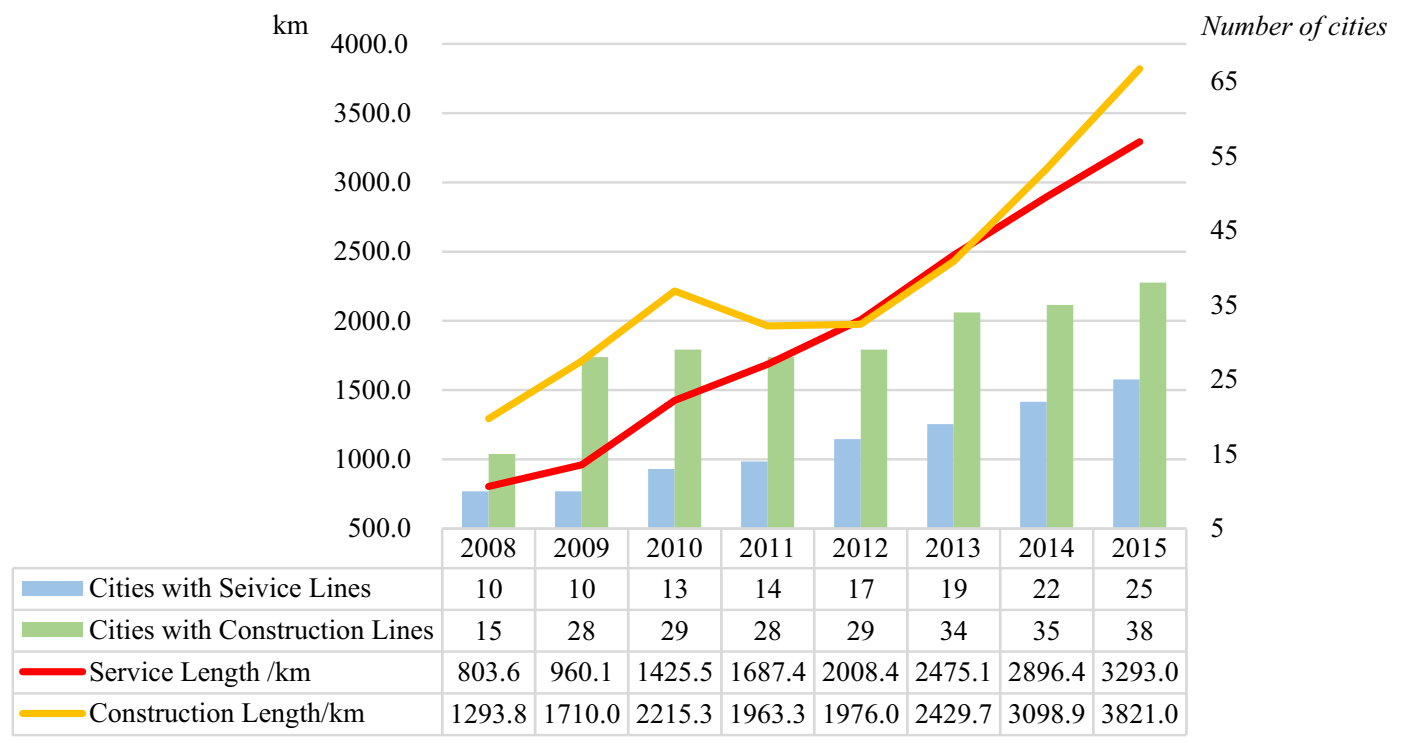

Fig. 1 Statistics of urban rail transit development in China from 2008 to 2015 [8-15]

*The lines and the histograms are distance and number of cities, respectively 


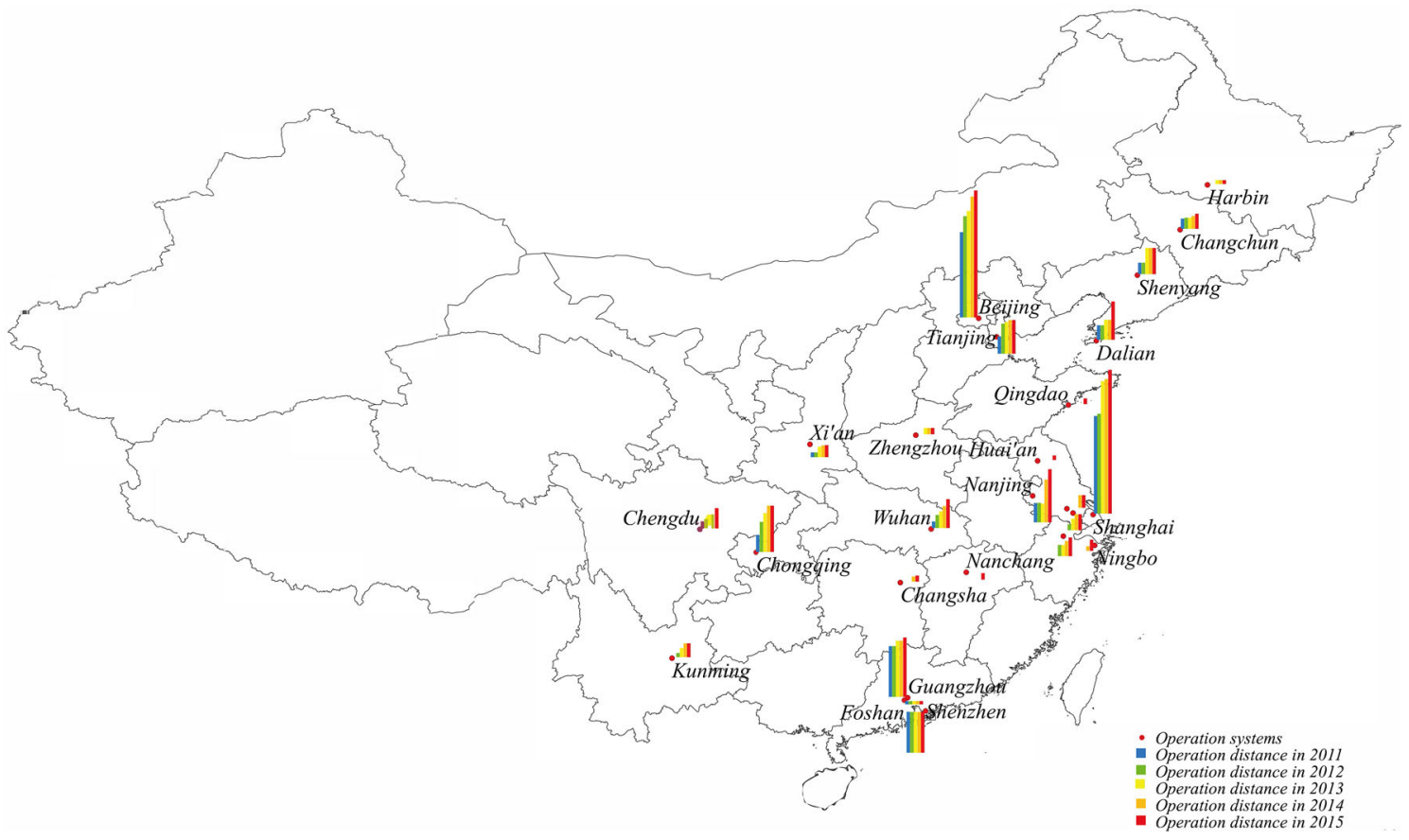

Fig. 2 Operation distance from 2011 to 2015 for each operational system

\subsection{Service Length and Socioeconomic Statistics}

This study summarized and analyzed the statistics of operation distance and spatial service coverage of urban rail transit systems in China. Some terminologies are clarified and defined firstly to make the data clear. The length in this study represents the service length, which is the length between the origin and destination of the line regardless of the dual-direction, rather than the track length. Usually, the metro lines are double-track, and the service length means half of the track length. However, there are some exceptions. Taking Beijing Airport line as an example, as shown in Fig. 3, this service line is a onedirection loop. The origin is Dongzhimen Station, via Sanyuanqiao Station, Beijing Airport Terminal 3, and after the train arrives at the destination of this service line, Beijing Airport Terminal 2, it will not return to Terminal 3 direction, but drive to Sanyuanqiao Station and finally return to its origin Dongzhimen Station. Trains run in the directions of the arrows. The service length is $28 \mathrm{~km}$, more than half of the track length $50.8 \mathrm{~km}$.

Meanwhile, the service length is independent of the operation loop. Taking Beijing Line 6 as an example, as shown in Fig. 4, during the evening peak hours there are two operation loops. The long loop is from Haidian Wuluju Station to Lucheng Station; both of the two stations are terminals. The shorter one is from Chegongzhuang West Station to Caofang Station, shown by the dashed line. The service length of Line 6 is the long loop, which is the distance between two terminals.
In China, almost every line operates separately and the trains run on the same line and seldom move across the line. However, there is one exception in Shanghai. For Shanghai Line 3 and Line 4, the same track from Baoshan Road Station to Yishan Road Station is shared by two lines (as shown in Fig. 5), which is very common in London and Paris. When calculating the service length of the network in Shanghai, the shared parts are counted twice.

The service length and socioeconomic data of the operational systems are listed in Table 1. The cities are ordered by the opening year of the city's first line.

Beijing has the largest number of operational lines, while the service length in Shanghai is the longest in 2015-given in Table 1. Beijing, Shanghai, Guangzhou, Shenzhen and Nanjing can be classified as the first development group. These cities have two characteristics in common. First, they have a higher level of economic development, and the average gross domestic product (GDP) was 1870 billion RMB (approximately equivalent to 287.7 billion US dollars). Second, these cities have a large population, approximately 15 million for every city on average.

\subsection{Passenger Service Performance}

In 2015, the urban rail transit system served a total number of 13.8 billion passengers, an increase of $9.5 \%$. Beijing, Shanghai and Guangzhou are the top three cities in terms of passenger volume, carrying over 6 million passengers every day, closely followed by Shenzhen, Nanjing, Chongqing and Wuhan. Urban rail transit system plays a 
Fig. 3 Beijing Airport line

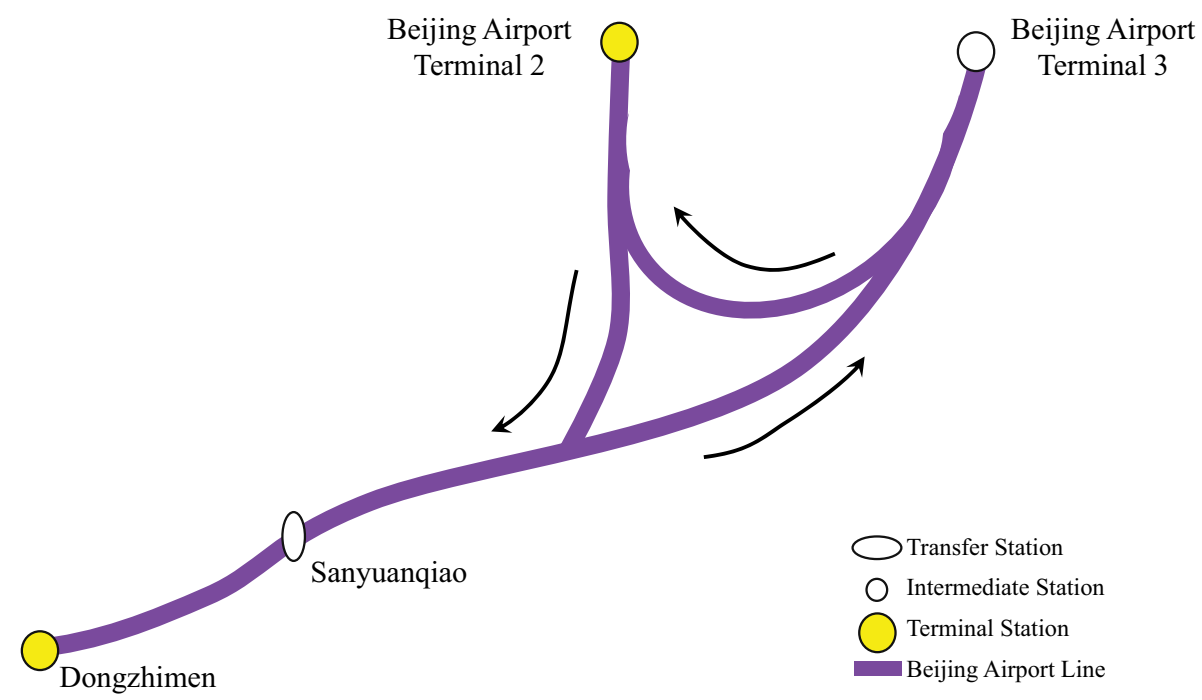

Fig. 4 Operation loop of Line 6 in Beijing

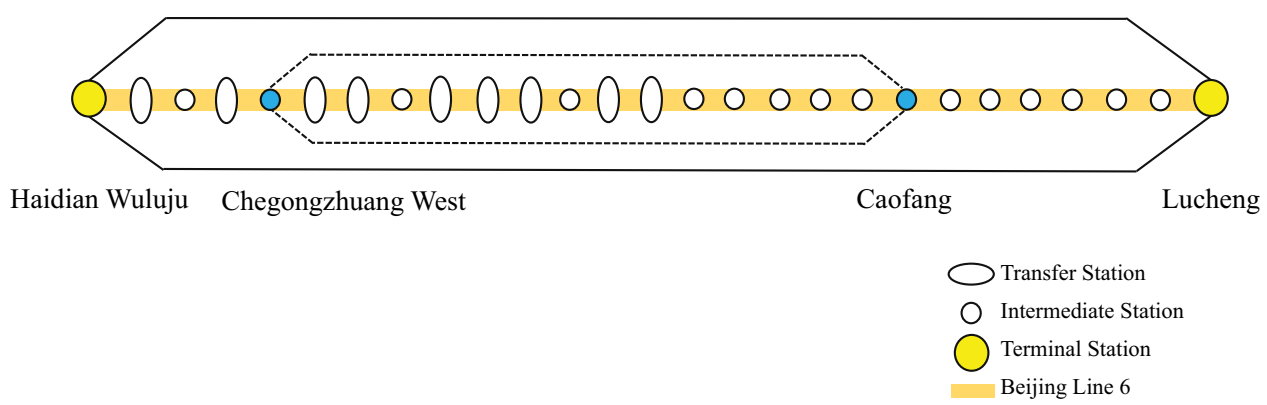

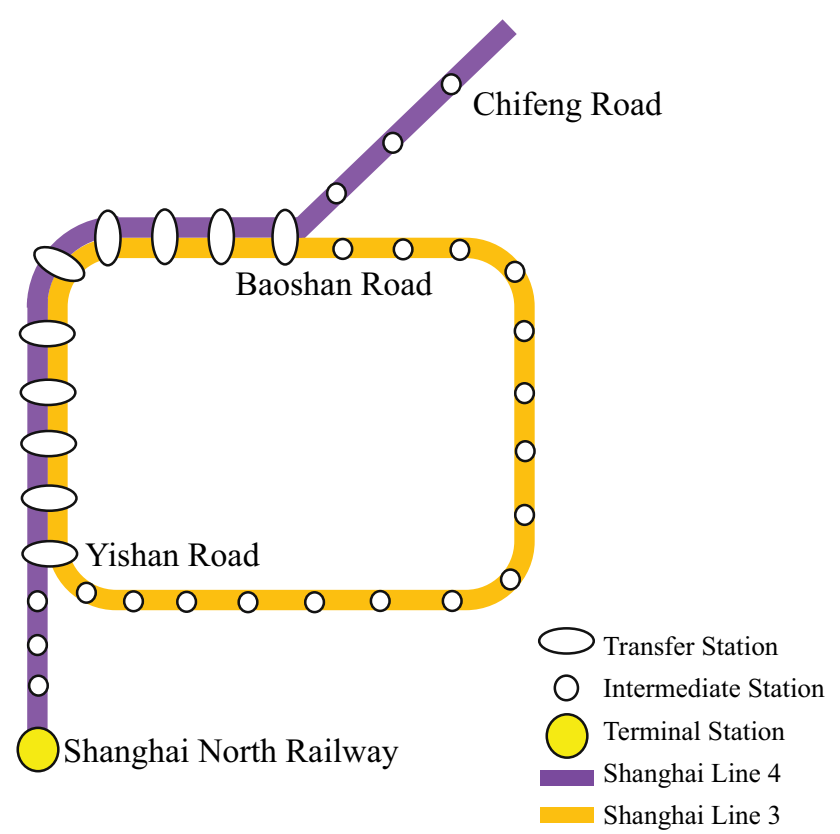

Fig. 5 Shared track in Shanghai urban rail significant role in inner city public transportation. More detailed information about passenger volume is given in Table 2 [5, 18].

The annual ridership increases every year, and most of the cities were under a great transportation pressure. The daily ridership in Beijing and Shanghai has reached 9.36 and 8.41 million, respectively. The average daily passenger flow intensity was 12.1 thousand passengers per km compared with 11.4 thousand passengers per $\mathrm{km}$ last year. Among these 25 cities, Guangzhou, carrying 6.44 million passengers every day with a service length of $259.81 \mathrm{~km}$, held the highest daily passenger intensity, which reached 24.8 thousand passengers per $\mathrm{km}$ and was almost two times higher than Shanghai and Beijing. There are some reasons for this result. In Guangzhou, most of the lines are in the downtown and the ridership is still high in the off-peak hours. However, in Beijing and Shanghai, some of the lines are on the outskirts of the city, which lowered the average passenger intensity of these cities. However, the passenger intensity in Beijing and Shanghai is significantly higher than in other cities except for Guangzhou, and they have 
Table 1 Service length and the socioeconomic indicators of operational systems in 2015 [15]

\begin{tabular}{|c|c|c|c|c|c|c|c|}
\hline ID & Cities & $\begin{array}{l}\text { Year } \\
\text { opened }\end{array}$ & $\begin{array}{l}\text { Service length } \\
(\mathrm{km})^{\mathrm{a}}[15]\end{array}$ & Lines & $\begin{array}{l}\text { Area } \\
\left(\mathrm{km}^{2}\right)^{\mathrm{b}}[17]\end{array}$ & $\begin{array}{l}\text { Population } \\
\text { (Millon) }^{\mathrm{c}}[17]\end{array}$ & $\begin{array}{l}\text { GDP (Billion } \\
\text { RMB) }{ }^{\mathrm{e}}[17]\end{array}$ \\
\hline 1 & Beijing & 1969 & 554.69 & 18 & 1268 & 21.520 & 2300 \\
\hline 2 & Shanghai & 1995 & 627.15 & 16 & 1563 & 24.260 & 2530 \\
\hline 3 & Guangzhou & 1999 & 259.81 & 10 & 700 & 13.081 & 1810 \\
\hline 4 & Changchun & 2002 & 65.55 & 4 & 222 & 27.524 & 565 \\
\hline 5 & Dalian & 2002 & 167.25 & 6 & 318 & $6.690^{\mathrm{d}}$ & 780 \\
\hline 6 & Tianjin & 2003 & 147.56 & 5 & 605 & 15.168 & 1720 \\
\hline 7 & Wuhan & 2004 & 126.18 & 4 & 408 & 10.338 & 1100 \\
\hline 8 & Shenzhen & 2004 & 178.59 & 5 & 661 & 10.779 & 1750 \\
\hline 9 & Nanjing & 2005 & 232.15 & 7 & 502 & 8.216 & 960 \\
\hline 10 & Chongqing & 2005 & 202.31 & 4 & 278 & 29.914 & 1610 \\
\hline 11 & Shenyang & 2010 & 114.57 & 6 & 399 & 8.287 & 728 \\
\hline 12 & Chengdu & 2010 & 88.50 & 3 & 406 & 14.428 & 1080 \\
\hline 13 & Foshan & 2010 & 14.80 & 1 & 373 & 7.351 & 820 \\
\hline 14 & Xi'an & 2011 & 52.30 & 2 & 359 & 8.628 & 600 \\
\hline 15 & Suzhou & 2012 & 70.50 & 3 & 411 & 10.604 & 1440 \\
\hline 16 & Hangzhou & 2012 & 81.35 & 3 & 551 & 8.892 & 1010 \\
\hline 17 & Kunming & 2012 & 60.00 & 3 & 269 & 6.626 & 405 \\
\hline 18 & Harbin & 2013 & 17.47 & 1 & 234 & $10.636^{\mathrm{d}}$ & 575 \\
\hline 19 & Zhengzhou & 2013 & 26.20 & 1 & 294 & 9.200 & 7450 \\
\hline 20 & Wuxi & 2014 & 55.72 & 2 & 372 & 6.500 & 8500 \\
\hline 21 & Changsha & 2014 & 26.58 & 1 & 190 & 7.312 & 8600 \\
\hline 22 & Ningbo & 2014 & 49.23 & 2 & 395 & 7.811 & 8000 \\
\hline 23 & Qingdao & 2015 & 25.20 & 1 & 337 & 9.046 & 9400 \\
\hline 24 & Nanchang & 2015 & 28.80 & 1 & 222 & 5.240 & 4000 \\
\hline 25 & Huai'an & 2015 & 20.30 & 1 & 56 & 2.375 & 789 \\
\hline
\end{tabular}

${ }^{a}$ The data were updated on December 31, 2015, and extracted from the 2015 Annual Report of China Urban Mass Transit

b The metropolis area of that city in 2014

c The permanent resident population by the end of 2014

d The permanent resident population by the end of 2010

e 2015 economic data from state statistics bureau in 2015 and 1 RMB $=0.15$ US dollar

reached 17 thousand passengers per $\mathrm{km}$ and 14 thousand passengers per $\mathrm{km}$, respectively. When only considering the lines in the downtown, the passenger intensity of Beijing and Shanghai reached over 20 thousand passengers per $\mathrm{km}$ and passenger intensity of some lines even went up to 40 thousand passengers per $\mathrm{km}$.

\subsection{Operational Efficiency}

Operational efficiency includes many aspects, such as train operation distance, train ownership, headway in peak hour, train travel velocity, energy consumption for each train. By the end of 2015, there were 3538 trains (except tram and monorail) working on the passenger transportation in the urban rail transit system in China and totally moving 2.02 billion kilometers, providing totally 34,810 train services every day on average with average $35 \mathrm{~km} / \mathrm{h}$ travel speed which is two times faster than buses.

As for the headway, in the peak hour, there are six cities where the headway is less than 3 min, especially in Beijing, where the headway is less than 2 min which is the shortest among these 25 operational systems in 2015, shortening by $17 \mathrm{~s}$ compared with 2014 . Meanwhile, the level of punctuality and security was high. In 2015, the average service time is $16.7 \mathrm{~h} / \mathrm{d}$ (hours per day), the longest service time is $18.6 \mathrm{~h} / \mathrm{d}$, and the shortest is $14.2 \mathrm{~h} /$ d. The delay, which was over $5 \mathrm{~min}$, happened 1791 times in 2015. The average delay is 0.87 times per million carkilometer, which related to the scale of service network and service modes.

As for the energy consumption, the average energy consumption for every passenger is $0.07 \mathrm{kw} \mathrm{h}$, much lower compared with other transportation modes. However, 
Table 2 Passenger service performance of urban rail transit system in 2015

\begin{tabular}{|c|c|c|c|c|c|}
\hline ID & City & $\begin{array}{l}\text { Annual ridership } \\
\text { (million/year) }\end{array}$ & $\begin{array}{l}\text { Annual passenger } \\
\text { transport turnover (billion } \\
\text { passenger } / \mathrm{km} \text { ) }\end{array}$ & $\begin{array}{l}\text { Daily ridership } \\
\text { (million passengers) }\end{array}$ & $\begin{array}{l}\text { Daily passenger } \\
\text { flow intensity } \\
\text { (thousand passenger } / \mathrm{km} \text { ) }\end{array}$ \\
\hline 1 & Beijing & 3416.10 & 28.03 & 9.36 & 16.9 \\
\hline 2 & Shanghai & 3067.98 & 27.00 & 8.41 & 13.4 \\
\hline 3 & Guangzhou & 2351.51 & 16.34 & 6.44 & 24.8 \\
\hline 4 & Changchun & 72.08 & 0.65 & 0.20 & 3.1 \\
\hline 5 & Dalian & 112.86 & 1.19 & 0.31 & 1.9 \\
\hline 6 & Tianjin & 287.15 & 3.46 & 0.79 & 5.4 \\
\hline 7 & Wuhan & 439.20 & 3.16 & 1.20 & 9.5 \\
\hline 8 & Shenzhen & 930.66 & 8.55 & 2.55 & 14.3 \\
\hline 9 & Nanjing & 716.66 & 5.87 & 1.96 & 8.4 \\
\hline 10 & Chongqing & 632.47 & 6.02 & 1.73 & 8.6 \\
\hline 11 & Shenyang & 282.91 & 2.18 & 0.78 & 6.8 \\
\hline 12 & Chengdu & 339.33 & 3.04 & 0.93 & 10.5 \\
\hline 13 & Foshan & 58.33 & 0.61 & 0.16 & 10.8 \\
\hline 14 & Xi'an & 342.09 & 1.11 & 0.94 & 18.0 \\
\hline 15 & Suzhou & 136.33 & 0.95 & 0.37 & 5.2 \\
\hline 16 & Hangzhou & 223.46 & 2.02 & 0.61 & 7.5 \\
\hline 17 & Kunming & 83.67 & 0.88 & 0.23 & 3.8 \\
\hline 18 & Harbin & 65.64 & 0.43 & 0.18 & 10.3 \\
\hline 19 & Zhengzhou & 88.10 & 0.78 & 0.24 & 9.2 \\
\hline 20 & Wuxi & 72.25 & 0.50 & 0.20 & 3.6 \\
\hline 21 & Changsha & 84.07 & 0.34 & 0.23 & 8.7 \\
\hline 22 & Ningbo & 37.76 & 0.21 & 0.10 & 2.0 \\
\hline 23 & Qingdao & 0.54 & 0.002 & 0.04 & 1.6 \\
\hline 24 & Nanchang & 1.40 & 0.10 & 0.23 & 8.0 \\
\hline 25 & Huai'an & - & - & - & - \\
\hline
\end{tabular}

Except for the five rapid rail and tram

because of the number of new lines and the growing passengers, the average energy consumption for every passenger is more than $0.2 \mathrm{kw} \mathrm{h}$ in Qingdao, Chongqing, Changsha and Wuxi. For the train energy consumption, the average is $3.74 \mathrm{kw}$ h per car-kilometer including $1.96 \mathrm{kw} \mathrm{h}$ from train traction. Because of the train type (B-type), monorail and tram, the energy consumption in Shenyang, Chongqing, Beijing, Nanjing, Nanjing and Kunming was much lower than the average. More detailed information about operational efficiency is given in Table 3.

\section{Implications and Trends of Urban Rail Transit in China}

\subsection{The Implication of URT in China}

Public transit is more than a means of transportation. It plays a critical role in facilitating the city's competitiveness. High-quality transport services and infrastructure improve the labor market performance, attract inward investments and help to create an improved quality of life. Below are examples of some research based on Minneapolis-St. Paul (MSP) area. Tilahun and Fan [19] found out that the growth of jobs along transitway corridors would achieve the best regional transit accessibility gains. From Fan, Guthrie and Levinson's [20] study, light rail stations and bus stops offering direct rail connections are associated with large, statistically significant gains in accessibility to low-wage jobs. Owen and Levinson [21] had demonstrated the feasibility of accessibility-based mode share modeling and predicted the likelihood that a commuter will choose transit rather than auto for a commute trip based on aggregate characteristics of the surrounding area. Fan and Guthrie [22] did an individual dimensions survey along four transit corridors in this area to explore the broader neighborhood impacts of transit investments as perceived by neighborhood residents. They found out some significant differences existed between urban and suburban areas and between individual 
Table 3 Operation service in 25 cities [18]

\begin{tabular}{|c|c|c|c|c|c|c|c|c|}
\hline ID & City & $\begin{array}{l}\text { Train operation distance } \\
\text { (million car-kilometer) }\end{array}$ & $\begin{array}{l}\text { Trains } \\
\text { ownership }\end{array}$ & $\begin{array}{l}\text { Daily train } \\
\text { service }\end{array}$ & $\begin{array}{l}\text { Headway in } \\
\text { peak hour (s) }\end{array}$ & $\begin{array}{l}\text { Travel } \\
\text { velocity } \\
\text { (kw h) }\end{array}$ & $\begin{array}{l}\text { Energy consumption } \\
\text { (million } \mathrm{kw} \mathrm{h} \text { ) }\end{array}$ & $\begin{array}{l}\text { Service } \\
\text { time }(\mathrm{h} / \mathrm{d})\end{array}$ \\
\hline 1 & Beijing & 509.09 & 839 & 7539 & 103 & 36 & 1585.85 & 18.6 \\
\hline 2 & Shanghai & 445.14 & 643 & 6600 & 135 & 36 & 1725.09 & 18.0 \\
\hline 3 & Guangzhou & 236.17 & 331 & 4712 & 132 & - & - & - \\
\hline 4 & Changchun & 10.28 & 68 & 697 & 270 & 28 & 42.00 & 15.9 \\
\hline 5 & Dalian & 25.90 & 92 & 858 & 210 & 39 & 65.39 & 14.9 \\
\hline 6 & Tianjin & 61.99 & 113 & 1038 & 270 & 38 & 264.75 & 16.9 \\
\hline 7 & Wuhan & 23.10 & - & 335 & - & - & - & - \\
\hline 8 & Shenzhen & 135.20 & 186 & 1695 & 165 & 36 & 609.50 & 17.6 \\
\hline 9 & Nanjing & 132.94 & 201 & 1941 & 140 & 44 & 428.88 & 17.0 \\
\hline 10 & Chongqing & 131.16 & 177 & 2156 & 150 & 44 & 428.34 & 16.5 \\
\hline 11 & Shenyang & 35.23 & 70 & 883 & 270 & 21 & 112.75 & 17.5 \\
\hline 12 & Chengdu & 56.57 & 122 & 1287 & 160 & 34 & 247.84 & 17.2 \\
\hline 13 & Foshan & 10.84 & 27 & 372 & 270 & 37 & 64.88 & 18.0 \\
\hline 14 & Xi'an & 39.62 & 324 & 350 & 240 & 34 & 158.48 & 17.0 \\
\hline 15 & Suzhou & 27.11 & 48 & 641 & 280 & 33 & 66.60 & 17.1 \\
\hline 16 & Hangzhou & 21.25 & 78 & 961 & 210 & 33 & 221.91 & 17.5 \\
\hline 17 & Kunming & 32.37 & 40 & 406 & 330 & 40 & 113.08 & 14.2 \\
\hline 18 & Harbin & 9.47 & 17 & 237 & 390 & 31 & - & - \\
\hline 19 & Zhengzhou & 16.14 & 25 & 283 & 283 & 33 & - & - \\
\hline 20 & Wuxi & 29.37 & 46 & 528 & 475 & 34 & 132.62 & 16.0 \\
\hline 21 & Changsha & 14.29 & 16 & 288 & 310 & 32 & 97.60 & - \\
\hline 22 & Ningbo & 16.02 & 46 & 538 & 360 & 33 & 101.92 & 16.0 \\
\hline 23 & Qingdao & 0.24 & 12 & 215 & 520 & 33 & 1.76 & 15.3 \\
\hline 24 & Nanchang & 0.04 & 17 & 250 & 480 & 32 & 22.32 & - \\
\hline 25 & Huai'an & - & - & - & - & - & - & - \\
\hline
\end{tabular}

neighborhoods. Tong et al. [23] constructed a time-dependent space-time network where the traveling arcs and activity performing arcs were introduced to analyze the accessibility of Chicago. Foth et al. [24] developed a methodology using a social indicator based on census tract level socioeconomic characteristics to measure the relationship between social disadvantage and accessibility to jobs and transit travel time in the Toronto region over time.

Meanwhile, more than improving the accessibility of the residents, the urban rail transit systems also have positive economic impacts on the cities. Knowles and Ferbrache [25] did a study on light rail systems, and they found out that the light rail systems improve the economic growth by increasing the attraction of locations for inward investment.

Urban rail in China has attracted fairly high ridership. Taking Beijing as an example, in 2015, the average passenger every day is 9.36 million and $25 \%$ of the commuters take the metro system to go to work, which is the same as the bus system. Every city tries to improve the coverage of the urban rail transit and provide higher accessibility to the residents. Table 4 gives out the line density and the service length sharing by residents in top 10 operational systems in
China. In Chongqing, the urban rail transit system covers most of the area in the city and its line density has reached $0.728 \mathrm{~km} / \mathrm{km}^{2}$. Dalian and Nanjing ranked the second and the third, respectively, having reached 0.526 and $0.462 \mathrm{~km} /$ $\mathrm{km}^{2}$. In terms of the service length per resident, Nanjing ranked in the first place and reached $0.0283 \mathrm{~m} /$ person, followed by Shanghai and Beijing.

Moreover, the government invested in the urban rail system steadily every year, and in 2015, the investment has reached to 368.3 billion RMB (approximately equivalent to 56.7 billion US dollars), and for the next 5 years. The urban rail transit will play a more and more significant role in public transportation. The trends of urban rail transit in China are discussed below.

\subsection{Trends of Urban Rail Transit in China in the Next Five Years}

\subsubsection{A Decade of Rapid and Large-Scale Development}

The urban rail transit system experienced a rapid development in China during the last 10 years. In the past 
Table 4 Special service of coverage of the top 10 operational systems

\begin{tabular}{llll}
\hline ID & Cities & $\begin{array}{l}\text { Line density } \\
\left(\mathrm{km} / \mathrm{km}^{2}\right)\end{array}$ & $\begin{array}{l}\text { Service length sharing by } \\
\text { population (m/person) }\end{array}$ \\
\hline 1 & Shanghai & 0.401 & 0.0259 \\
2 & Beijing & 0.437 & 0.0258 \\
3 & Guangzhou & 0.371 & 0.0199 \\
4 & Nanjing & 0.462 & 0.0283 \\
5 & Chongqing & 0.728 & 0.0068 \\
6 & Shenzhen & 0.270 & 0.0166 \\
7 & Dalian & 0.526 & 0.0250 \\
8 & Tianjin & 0.244 & 0.0097 \\
9 & Wuhan & 0.309 & 0.0122 \\
10 & Shenyang & 0.287 & 0.0138 \\
\hline
\end{tabular}

5 years, $1867.5 \mathrm{~km}$ of new lines was opened. In the next 5 years, the urban rail transit in China will continue to grow. Figure 5 shows the distribution of the cities with urban rail transit. The dashed line is the Heihe-Tengchong Line or population density line. On the east, it covers $95 \%$ of the population in China, $43 \%$ of China's area, and lies in regions where the economy is more developed. All of the cities with urban rail transit service are under the dashed line. Most of the cities are distributed in the big cities of the province and the coastline area of China, especially in the Yangtze River Delta region (the blue dashed ellipse in Fig. 6) and Pearl River Delta region (the pink dashed ellipse in Fig. 6) [26]. However, some cities in the west part of China have started to construct urban rail transit systems, such as Urumchi and Lanzhou. Because of the limited road density, for instance, in 2004, Beijing road network was $14,557 \mathrm{~km}$ with $1 \mathrm{~m} /$ capita length of road Ahmed et al. [27]; in order to mitigate the traffic problem, the urban rail transit systems are constructed. There were in total $3821 \mathrm{~km}, 147$ urban rail transit lines under construction in 38 cities by the end of 2015. By the end of 2020 , over $3000 \mathrm{~km}$ new lines will be opened and the total service length will reach up to $6000 \mathrm{~km}$. The proportion of urban rail transit in public transportation will increase.

During the past 5 years, the investment for urban rail transit in China is 1228.9 billion RMB (approximately equivalent to 189.1 billion US dollars) in total, as shown in Fig. 7. The average investment is 245.8 billion RMB (approximately equivalent to 37.8 billion US dollars), with a steady growth of 51.4 billion every year. In the next 5 years, the total investment will reach up to 1700-2000 billion RMB and some new investment mode such as PPP (Public-private partnership) will be adopted [28-30].

Meanwhile, there were 55 cities planning to build urban rail transit systems by the end of 2015. Table 5 shows the urban rail transit planning in every city with operation lines. Almost every city plans to construct urban rail transit systems with a length of more than $500 \mathrm{~km}$. The total planning length will reach $15,000 \mathrm{~km}$ in China. The construction work for the next 5 years is a big challenge.

\subsubsection{Attraction of More Passengers}

In the past 5 years, there were totally 52.8 million passengers choosing urban rail transit. The annual ridership from 2011 to 2015 is shown in Fig. 8. Passenger travel behaviors changed a lot during these 5 years. With the development of urban rail transit and the network operation, the passenger volume is expected beyond 16 million in 2016. The total passenger volume for the next 5 years will be over 100 million.

\subsubsection{Network Organization Patterns}

By the end of 2015, there were 10 cities whose service length will reach more than $100 \mathrm{~km}$ and 18 cities building more than two lines. There were 384 transfer stations, which accounted for $17.2 \%$ of all stations in service. Meanwhile, there are 2075 stations under construction, in which the transfer stations reached 609 and occupied $29.3 \%$ of the total stations. The increasing proportion of the transfer station indicates that the urban rail transit lines have evolved into a network where different lines intersect and correlate with each other, instead of a single line. At the same time, the ridership is increasing during these 5 years. In Beijing, the daily ridership increased from 5.97 million in 2011 to 9.36 million in 2015 [31], an increase of $56.8 \%$. For some transfer stations, such as Xizhimen Station, the daily ridership is over 1 billion. In order to integrate resources and the passenger flow, many cities with urban rail transit in China are exploring transport organization patterns under network operation, such as flexible marshaling and express and local trains [32-34].

Flexible marshaling According to the passenger characteristics, the trains can be marshaled flexibly which could not only save transport capacity but also improve service levels. In April 


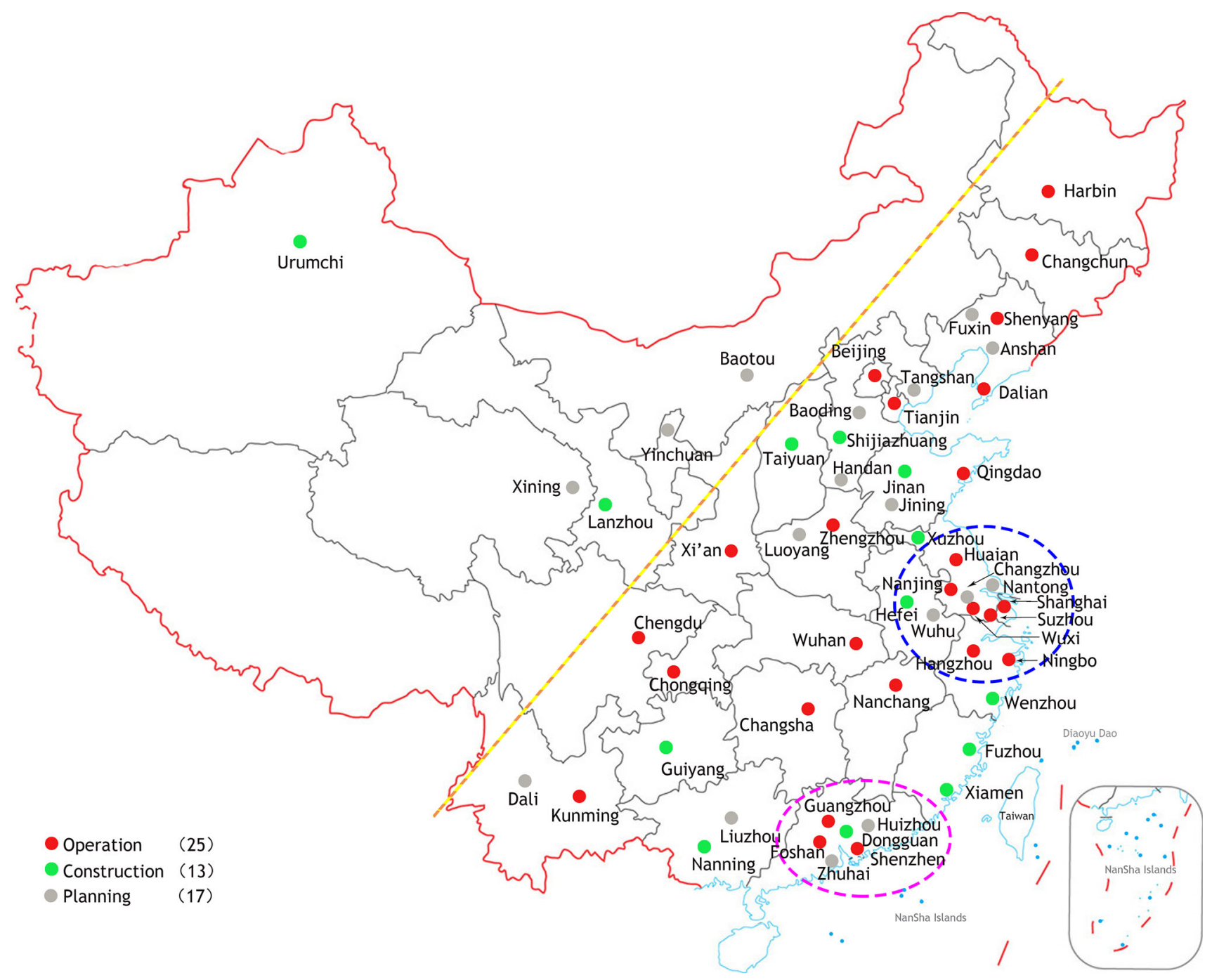

Fig. 6 Distribution of the systems with urban rail transit

Fig. 7 Investment of urban rail in China in past 5 years

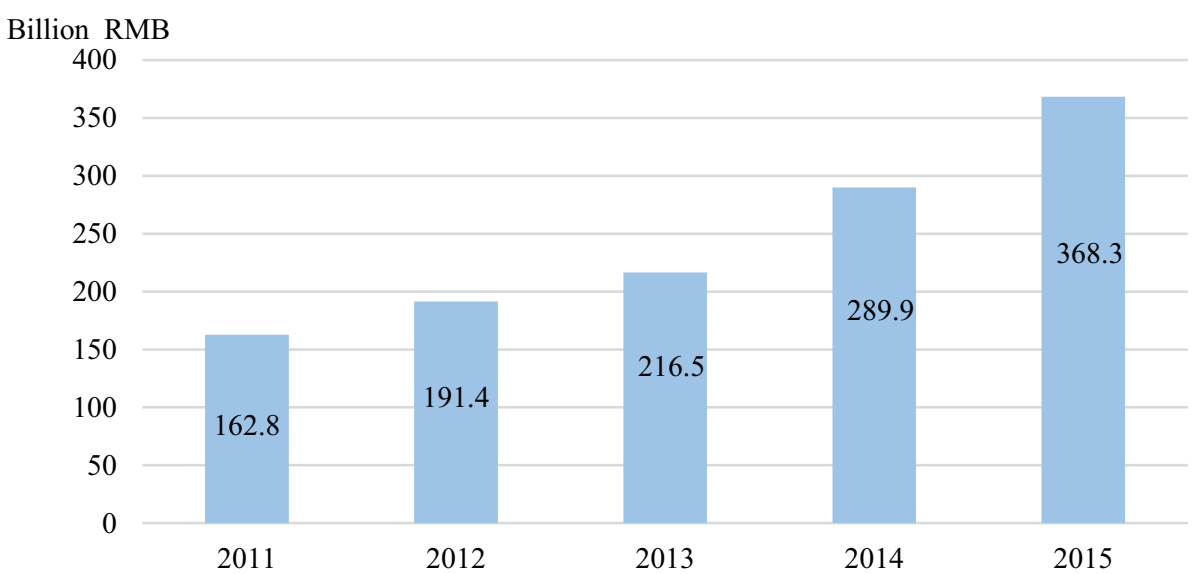

2010, Guangzhou Metro Line 3 first adopted flexible marshaling technology, with a unit of three cars. During peak hours, the train is marshaled with two units and one unit during off-peak hours to adapt to the tide phenomenon of the passenger flow. Similar to Guangzhou Metro Line 3, Shanghai Metro Line 16 uses the same marshaling mode [35, 36].

Long-short loop Besides Beijing Metro Line 6, as shown in Fig. 4, Beijing Metro Line 4 and Shanghai Metro 
Table 5 Urban rail transit network planning distance [15]

Fig. 8 Annual ridership from 2011 to 2015

\begin{tabular}{lllcllll}
\hline ID & City & Planning period & Length $(\mathrm{km})$ & ID & City & Plan period & Length $(\mathrm{km})$ \\
\hline 1 & Beijing & $2007-2016$ & 664 & 14 & Xi'an & $2013-2018$ & 252 \\
2 & Shanghai & now-2020 & 1051 & 15 & Suzhou & $2016-2022$ & 391.4 \\
3 & Guangzhou & now-2040 & 1025 & 16 & Hangzhou & $2003-2019$ & 190 \\
4 & Tianjin & $2015-2020$ & 1380 & 17 & Kunming & $2011-2050$ & 296.7 \\
5 & Shenzhen & $2010-2020$ & 597 & 18 & Harbin & $2010-2040$ & 340 \\
6 & Nanjing & now-2050 & 914 & 19 & Zhengzhou & $2013-2019$ & 359.7 \\
7 & Chongqing & $2012-2020$ & 820 & 20 & Changsha & $2012-2050$ & 456 \\
8 & Changchun & $2020-2030$ & 257 & 21 & Ningbo & $2013-2020$ & 100 \\
9 & Wuhan & $2014-2049$ & 1045 & 22 & Wuxi & - & 93.94 \\
10 & Dalian & $2014-2020$ & 887 & 23 & Qingdao & Long-term plan & 807 \\
11 & Shenyang & $2020-2050$ & 610 & 24 & Nanchang & $2020-2050$ & 198 \\
12 & Chengdu & $2011-2020$ & 1117 & 25 & Huai'an & $2015-2050$ & 199.5 \\
13 & Foshan & - & 264 & 26 & Total & & $14,314.24$ \\
\hline
\end{tabular}

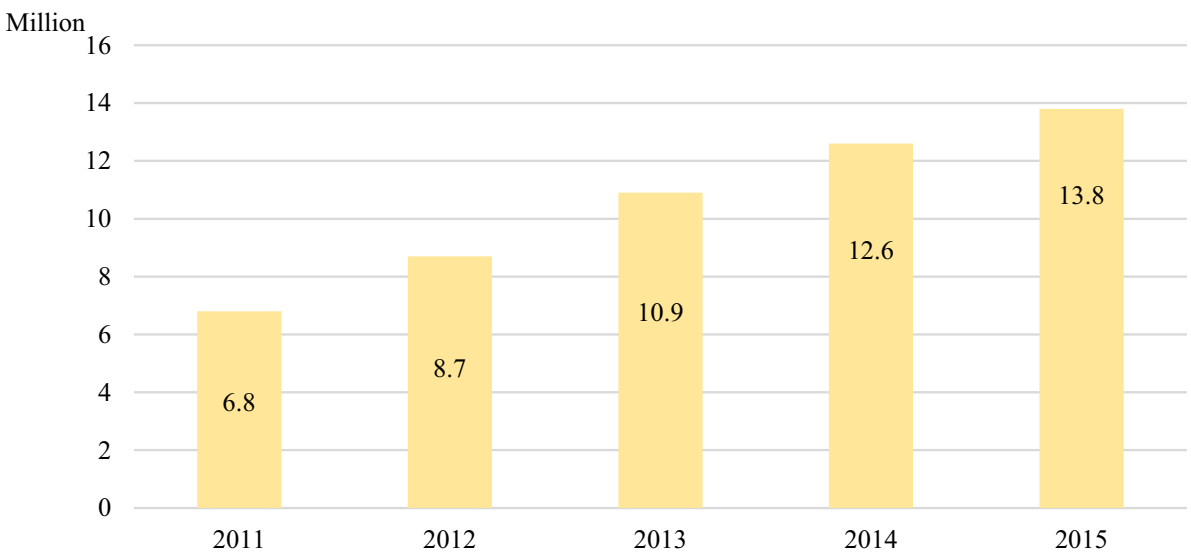

Line 2 are also using the long-short loop organization pattern.

Express-local train The essence of express and local train operation is to decide the stopping of express trains and local trains based on the section passenger volume, with the express train stopping at fewer stations and traveling less time. This pattern has an advantage in reasonably distributing transport capacity, cutting down traveling time of long-distance passengers and improving transportation efficiency of the system. In China, such as Beijing Metro Line 6, express trains and local trains run on separate tracks, while in Shanghai Metro Line 16, the express trains and local trains will run on the same track with four overtaking stations [37-39].

Feeder bus To guarantee the passenger demand, it is inevitable for urban rail transit to cooperate with other public transportation. With the coordination of the Traffic Committee of Guangzhou, Guangzhou Metro has enhanced the cooperation with Guangzhou Bus Company establishing a long-term cooperation. Once emergent events occur, free feeder buses will be provided to ease the transportation pressure of urban rail transit greatly and bring convenience for passengers [40-43].

Besides these operation strategies, some of the cities consider the network comprehensively and connect the lines together. Chongqing is working on the interconnection project and has tried to improve the flexibility of operation for different lines. Meanwhile, there is an urban rail transit planning for the Yangtze River Delta region and Pearl River Delta region in the next 5 years, and some new operation strategies will be developed to cater to the needs of the passengers.

\subsubsection{Multi-type Urban Rail Transit}

China is such a vast area, and the land use and landscape vary. Every city has its own characteristics. For example, Chongqing is located in the southwest of China and is mainly covered by hills and mountains. The unique landscape promoted the development of monorails, which have the outstanding capability of climbing steep slopes [44]. Meanwhile, the investment of tram construction is much 
less than that of the metro, and the capacity of the tram can meet the demand of the public transportation in some small cities, such as Changchun, Shenyang and Dalian, as shown in Fig. 9. Meanwhile, in the past 5 years, other types of public transportation such as APM (automated people mover systems) and light rail transit developed. Figure 9 indicates the urban rail transit type in every operational system.

In 2015, the proportion of metro system has decreased to $67 \%$ in terms of the urban rail transit projects under construction. In the next 5 years, the city scale will increase and stretch to suburb areas and some satellite cities. In order to connect with the downtown and satellite cities, considering the passenger flow and construction cost, more and more cities will choose the tram and light rail instead of the metro system. Some cities surrounding by hills will select the monorail to handle the huge passenger demand $[45,46]$.

With the rapid development of urban rail transit in China, we also can share the experience with other developing mega cities such as Karachi, Hanoi, Mumbai and Delhi. In the next 5 years, in order to develop the urban rail transit sustainably, we should integrate the land use and transportation, improve the traffic management and promote public transport and development based on transitoriented development [27].

\section{Conclusions}

This study provided official and compressive statistical data about the unprecedented fast development of urban rail transit in China and the corresponding socioeconomic background and reviewed the spatial service coverage, passenger service performance and operational efficiency, which provided the reliable data for research and government decision making. Four characteristics of this boom in urban rail transit are summarized. For the past 5 years, the average investment is 245.8 billion RMB (approximately equivalent to 37.8 billion US dollars), with a steady growth of 51.4 billion every year. The annual ridership is 10.5 million and increasing steadily, and the passenger flows in Beijing, Shanghai and Guangzhou are saturated during the peak hour. In order to carry those passengers more efficiently, some network organization patterns such as flexible marshaling, long-short loop and express-local train are used. Some new operation strategies are also been applied in some cities to seek the best way to cater to the demand of the passengers and improve the service level of urban rain transit. Meanwhile, more than one type of urban rail transit such as tram and monorail has been operated in other cities. Considering the financial investment, the landscape of the city and passenger demand, some cities

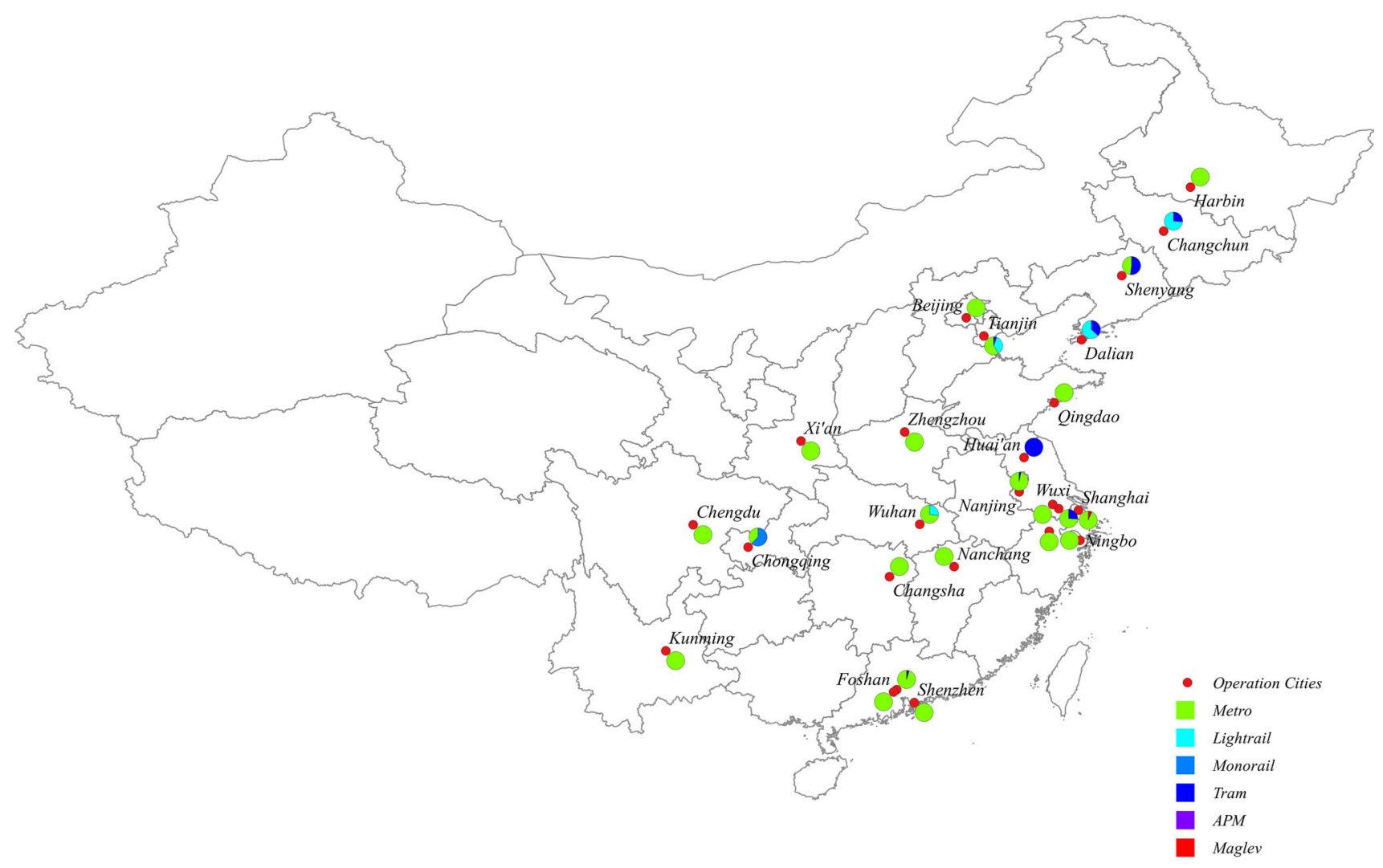

Fig. 9 Distribution of urban rail transit type in operational systems 
have operated the tram, monorail and light rail system instead of the metro system. Those urban rail systems worked well in mitigating traffic congestion and meeting the passenger demand. According to these characteristics and the progress review of the past 5 years, in 2016, the service distance in China will reach $3800 \mathrm{~km}$ attracting more than 16 million passengers. The total investment will reach up to 1700-2000 billion RMB (approximately equivalent to 261.5-307.7 billion US dollars) with the new investment and financing modes. The urban rail transit will still experience a rapid development in next 5 years and will play a more important role in public transportation. Moreover, the lessons learned from mega cities in China can be shared with other developing mega cities such as Karachi, Hanoi, Mumbai and Delhi.

Acknowledgements This study was supported by the National Natural Science Foundation Project (U1434207) of People's Republic of China, the Beijing Municipal Natural Science Foundation (8162033) and the Foundation of China Scholarship Council. The authors thank the editors of the journal and the anonymous reviewers for their constructive suggestions and comments that have led to a significant improvement in this paper.

\section{Compliance with Ethical Standards}

Conflict of interest The authors declare that there is no conflict of interest regarding the publication of this paper.

Open Access This article is distributed under the terms of the Creative Commons Attribution 4.0 International License (http://crea tivecommons.org/licenses/by/4.0/), which permits unrestricted use, distribution, and reproduction in any medium, provided you give appropriate credit to the original author(s) and the source, provide a link to the Creative Commons license, and indicate if changes were made.

\section{References}

1. The 2015 Urban Mobility Report (2015) Texas A\&M Transportation Institute, College Station, Texas. Available: http:// mobility.tamu.edu/ums/report/

2. 2013 Status of the Nation's Highways, Bridges, and Transit: Conditions and Performance (2014) National Technical Information Service, Federal Highway Administration, Federal Transit Administration. http://www.fhwa.dot.gov/policy/2013cpr/

3. Transportation Statistics Annual Report (2015) US Department of Transportation. 2015. http://www.rita.dot.gov/bts/publications/ transportation_in_the_united_states_2015/index.html

4. Mass Mobility Reports: The Massachusetts Community Transportation Series 2013. Human Service Transportation Office. 2013. http://www.mass.gov/eohhs/gov/commissions-and-initia tives/hst/annual-reports.html

5. Urban rail transit in China. https://en.wikipedia.org/wiki/Urban rail_transit_in_China. Accessed 28 Sept 2016

6. Transportation in Canada 2015 (2016) Minister of Transport. 2016. http://www.tc.gc.ca/eng/policy/anre-menu.html

7. Railway statistic. State Railway Administration, China. 2015. http://www.moc.gov.cn/tongjishuju/tielu/201603/t20160314_1999 755.html
8. Report of China urban mass transit editorial team (2009) 2008 Annual report of China urban mass transit. Beijing Jiaotong University Press, Beijing

9. Report of China urban mass transit editorial team (2010) 2011 Annual report of China urban mass transit. Beijing Jiaotong University Press, Beijing

10. Report of China urban mass transit editorial team (2011) 2010 Annual report of China urban mass transit. Beijing Jiaotong University Press, Beijing

11. Report of China urban mass transit editorial team (2012) 2011 Annual report of China urban mass transit. Beijing Jiaotong University Press, Beijing

12. Report of China urban mass transit editorial team (2013) 2012 Annual report of China urban mass transit. Beijing Jiaotong University Press, Beijing

13. Report of China urban mass transit editorial team (2014) 2013 Annual report of China urban mass transit. Beijing Jiaotong University Press, Beijing

14. Report of China urban mass transit editorial team (2015) 2014 Annual report of China urban mass transit. Beijing Jiaotong University Press, Beijing

15. Report of China urban mass transit editorial team (2016) 2015 Annual report of China urban mass transit. Beijing Jiaotong University Press, Beijing

16. National data (2016) National Bureau of Statistics of China, Beijing. http://data.stats.gov.cn/. Accessed 5 Feb 2016

17. National data (2015) National Bureau of Statistics of China, Beijing. http://data.stats.gov.cn/. Accessed 25 May 2016

18. China Association of Metros, Beijing. http://www.camet.org.cn/ sjtj/. Accessed 10 Aug 2016

19. Tilahun N, Fan Y (2014) Transit and job accessibility: an empirical study of access to competitive clusters and regional growth strategies for enhancing transit accessibility. Transp Policy 33:17-25

20. Fan Y, Guthrie A, Levinson DM (2010) Impact of light rail implementation on labor market accessibility: a transportation equity perspective. J Transp Land use 5(3):1-25

21. Owen A, Levinson DM (2015) Modeling the commute mode share of transit using continuous accessibility to jobs. Transp Res Part A Policy Pract 74:110-122

22. Fan Y, Guthrie A (2012) Winners or losers: resident perceptions of transit-induced neighborhood change. Transp Res Rec J Transp Res Board 2276:89-100

23. Tong L, Zhou X, Miller HJ (2015) Transportation network design for maximizing space-time accessibility. Transp Res Part B Methodol 81:555-576

24. Foth N, Manaugh K, El-Geneidy AM (2013) Towards equitable transit: examining transit accessibility and social need in Toronto, Canada, 1996-2006. J Transp Geogr 29:1-10

25. Knowles R, Ferbrache F (2014) An investigation into the economic impacts on cities of investment in light rail systems. Birmingham, CENTRO UK, Tram

26. Zhang S (2016) Perfect the rail transit network of the urban agglomerations with world class of the Yangtze River Delta. Urban Mass Transit 19(8):I0001

27. Ahmed QI, Lu H, Ye S (2008) Urban transportation and equity: a case study of Beijing and Karachi. Transp Res Part A Policy Pract 42(1):125-139

28. Huang B, Wang XC (2002) Ponderation on the model of urban rail transit constructions investing and financing. Urban Mass Transit 1:14-17

29. $\mathrm{Pu} \mathrm{W}, \mathrm{Xu} \mathrm{F}$, Huang CS (2016) Comparative analysis of the investment and financing modes of PPP, ABS and TOD in urban rail transit. J Transp Eng Inf 2:69-75

30. Wang C, Wu D, Hu YS et al (2015) Financing mode of urban rail transit project: a cased-based comparison. Urban Mass Transit $18(8): 22-25$ 
31. Beijing Subway. https://en.wikipedia.org/wiki/Beijing_Subway. Accessed 28 Sept 2016

32. He L, Liang Q, Fang S (2016) Challenges and innovative solutions in urban rail transit network operations and management: China's Guangzhou metro experience. Urban Rail Transit 2(1):33-45

33. He L, Fang SY, Liang QS (2015) Urban rail transit network operation: challenges and countermeasures. Urban Rapid Rail Transit 28(2):1-5

34. Zheng L, Xiao Y, He BS et al (2015) Analysis on network operation mode of urban rail transit and its characteristics. Railw Transp Econ 37(4):69-73

35. Lei XY, Yang GF, Yi CY et al (2015) Discussion on flexible formation of rail transit and its characteristics of combined transport organization. Railw Transp Econ 37(9):64-69

36. Yu DD, Han BM, Zhang Q et al (2015) Optimization method for train plan of urban rail transit based on the flexible length of train formation. J Beijing Jiaotong Univ 39(6):21-31

37. Zhang HN, Liang QH, Liu C (2015) Hints on chongqing rail transit from tsukuba express and local train operation mode. Urban Rapid Rail Transit 28(5):21-26
38. Zhang C, Han BM, Zhang Q (2015) Optimization methods of express and local train skip-stop scheme on airport rail line. Urban Rapid Rail Transit 28(5):67-70

39. Wang ZP, Luo X (2015) Stopping schedule optimization of express/local trains in urban rail transit. J South China Univ Technol Nat Sci Edition 43(12):91-98

40. Liu Y, Xu YG (2015) Study on collaborative construction of transfer facilities for urban rail and other different transport modes. Urban Rapid Rail Transit 28(4):27-31

41. Han F (2015) Research on urban rail transit access design approach and case study. Urban Rapid Rail Transit 28(3):46-48

42. Zhou JZ (2016) Joint selection model of urban rail transit access modes based on trip chain. Railw Stand Des 4:4-7

43. Feng MH, Gu BN (2015) Joint configuration method of urban railway feeder bus routes. Urban Mass Transit 18(3):73-76

44. He X (2016) Application and prospect of straddle monorail transit system in China. Urban Rail Transit 1(1):26-34

45. Wei C, Gu BN (2008) The typical modern tramsystems in Europe. Urban Mass Transit. 11(1):11-14

46. Zhong J (2009) Idea of green light rail reflected and developed in Chongqing rail transit. Urban Rapid Rail Transit 22(1):2-6 